retard the earth's rotation, but this is exactly balanced by the cotnter-trades of the circumpolar vortexes, blowing from west to east.

I cannot agree with Mr. Clement Ley when he says that it involves a fallacy to explain the mean winds, or great currents, on one principle, and the actual winds, or temporary currents, on another. If the great currents were much feebler in proportion to the temporary currents than they are, the mean prevalence of east winds in the tropics, and of west winds in the higher latitudes, would be discernible only as a residual fact when a number of anemometric observations made at various places were completely discussed. JOSEPH JOHN MURPHY

\section{The Germ Theory}

YouR number for March 22 contains a review of my work on the Germ Theory of Disease, which, in some points, conveys so erroneous an impression of my exact position that I must ask you to allow me space for a few remarks regarding it.

Adverse criticism is what the author of such a book as mine expects, and, to some extent, desires.

A fair representation of his views and arguments, is what every author may insist on as a right.

It is the misleading manner in which my position is stated in your review that has induced me to pen this note.

To or e or two of your statements I would refer in illustration of what I complain.

$\Lambda$ fter referring to my expressed belief that contagia are living organised particles - an opinion held by many eminent physicians and men of science-your reviewer says: "If, however, the particles in sheep-pox, small-pox, and vaccine be the infecting matter, they are easily seen by the microscope, and ought, therefore, to be found in the blood, but such is not the case." This, the old and stock argument against the germ theory, is specially dealt with by me on two different occasions-at p. 25 , et seq., and at p. 204, et seq. If it was worth your reviewer's while to raise this old objection to the germ theory, it was equally worth his while to make some reference to my explanation of the fact on which it rests. This he has not done-a manifest unfairness

A little further on the review says : "Increased elimination of urea is explained thus: The increased consumption of liguor sangrainis by the contagizm particles leads to increased formation of retrogressive albunnen and of wrea. It seems by this that contagium particles have livers and kidneys."

The part which I put in italics is put in your review within inverted commas, conveying thereby the impression that it is a correct quotation from my book. It is far from being so. As given by you, it is a misquoted short passage, separated from its context, and altered to suit the purpose of your review.

The chapter on increased elimination of urea is perfectly clear and intelligible to any ordinary mind, and contains nothing which justifies your reviewer in attributing to me, as he has done, the absurd belief that contagia are possessed of livers and kidneys. Neither is he justified in using the words "eat" and "drink" to express the action of a minute organism on its enviromment. Such phraseology can serve only to mislead those who are ignorant of the mode in which these organisms grow; and is quite inapplicable to any nutritive process which goes on in such organisms as I have described contagia to be.

Your reviewer quotes my statement that "if we were to oleed, to purge, to give antimony to, or even simply to withhold food and water from all the cases of typhus and enteric fever which occur, there can be no doubt that we should find the mortality from these diseases greatly increased ;" and remarks on this, "Dr. Maclagan is right here, for by simply withtholding food and water there can be no doubt that he would greatly increase the mortality by starving his patients to death." Your reviewer seems to be unaware that $I$ refer in these remarks to a mode of treating fever which at one time did prevail.

To one other point I would refer in illustration of your reviewer's inaccuracy.

He says "the heat of specific fevers is partly ascribed to the propagation of the contagium causing increased consumption of tissue. But increase of living matter causes the disappearance of heat, not its production."

Even according to this, your reviewer's own somewhat awkward statement of the matter, the increased heat is attributed by me to increased consumption of tissue, indirectly brought about by the propagation of the contagium. Nowhere do I say that in. crease of living matter causes production of heat ; and nowhere does your reviewer attribute such a statement to me. Quite the contrary. I distinctly say that the increased production of heat results from increased disintegration of the tissues; and your reviewer distinctly attributes this saying to me. What, then, is the meaning of the latter part of the sentence just quoted? It bears but one interpretation. Your reviewer attaches to the first half of the quotation a meaning the reverse of that which it conveys. While saying that I ascribe the increased heat to increased consumption of tissue, he seems to think that he is saying something quite different, and pens his criticism accordingly. If he thus misunderstands his own statements, I need, perhaps, scarcely be surprised at his sometimes misinterpreting mine. I do object, however, to such misinterpretations and inaccuracies appearing in so influential a journal as NATURE. Dundee

T, MAClaGaN

SEXUALITY IN PLANTS 1

THE concluding part of the tenth volume of Pringsheim's Fahrbuicher contains three papers, one of them by Dr. Arnold Dodel, of Zurich, being of the highest importance. This paper occupies the greater part of the present Heft, and is illustrated by eight coloured plates. The title is "Ulothrix zonata, its Sexual. and Non-Sexual Reproduction, a Contribution to the Knowledge of the Lower Limit of Sexuality in Plants." The anatomy and life-history of the Ulothrix is exhaustively treated, the whole paper being a model of careful and accurate research, as well as a valuable contribution to our knowledge of the lower plants. The paper is divided into sections, of which the following is a short summary. The results given are those obtained during fourteen months' consecutive observation of the plant. The genus Ulothrix has been divided into many species, but Dodel shows that $U$. zonata is so variable in its different stages that most of the so-called species must be reduced to one. The alternation of generations is very remarkable and divisible into four stages. During the progress of the alternation of generation three distinct forms are to be distinguished, two being filamentous generations, and the third a zygospore generation. The filamentous generations are invariably produced non-sexually and reproduce themselves repeatedly, forming, in fact, the plant known to systematic botanists as Ulothrix zonata. The third generation, the zygospore, was unknown till discovered by Dodel. In the long series of filamentous generations two distinct forms are to be distinguished. The first is produced non-sexually and is the autumn or winter generation. It develops non-sexual macrozoospores and quickly spreads the species in a given locality. The second is a sexual stage developing microzoospores. It arises from the non-sexual macrozoospore, and gives rise to the microzoospores which by conjugation form the third generation, the zygospore or zoozygospore.

The production of the microzoospore-forming generation terminates the series of filamentous generations. This stage is found in spring and summer, and by giving rise to the zygospores which by remaining in a state of rest for some months during the hot dry summer weather, reproduce the plant in the autumn. During the hot weather the filamentous generations more or less completely disappear. The zygospore generation, although a product of gamogenesis, is itself non-sexual.

Ulothrix zonata exhibits polymorphism in a remarkable degree, hence many forms looked upon as distinct species must be suppressed. This opens up a wide question in regard to other algæ, and shows how essential it is to obtain an accurate knowledge of the life-history of all forms.

The cells of Ulothrix give rise to a variable number of zoospores. A mother cell may form $1,2,4,8,16$, or 32 zoospores, thele being no obvious distinctions between the sexual and non-sexual zoospores. On the one side is the large macrozoospore with four cilia, and then there is every gradation down to the smallest microzoospore

I Jahrbücher für wissenschaftliche Botanik. Herarisgegeben von Dr. N' Pringsheim. Zehnter Band, Viertes Heft. Leipzig: Engelmam, $x 876$. 
which conjugates, and which is furnished with only two cilia. The only distinction between the macro- and microzoospores seems to be that the former have four cilia, the latter only two. When the microzoospores fail to conjugate they may develop non-sexually just like the macrozoospores. This is a fact of the highest importance. In this plant, belonging to the lowest group in. which sexual reproduction occurs, the sexual and non-sexual zoospores are hardly to be distinguished, and if by any chance union of the sexual zoospores does not take place, the zoospore behaves like a macrozoospore and develops non-sexually.

After remaining in a state of rest, sometimes for nearly twelve months, the contents of the zygospore break up into zoospores, from which arise the filamentous stage of. Ulothrix.

In Ulothrix the conjugating cells are generally morphologically and physiologically identical, but sometimes larger zoospores conjugate with smaller, a difference in sex being bere indicated. In other cases the microzoospores which have not conjugated germinate and give rise to individuals capable of reproducing. The study of the formation and subsequent development of the zygospore shows that the product of conjugation is to be considered as a new sexually-produced generation. It is a unicellular plantlet, with a root-like process and a slowly-growing plant-body which performs the function of assimilation. It in fact represents the embryo and the sporophore of the Pteridophytes. The root-end of the plantlet is formed by the union of the germinal spots of the conjugating microzoospores, while the assimilating plant-body represents the united chlorophyll-bearing parts of the zoospore.

The Ulothrix is thus one of the Zygosporeæ, and is probably related to Hydrodictyon, but it shows certain affinities to Sphreroplea, the lowest of the Oosporeæ.

As this part concludes the tenth volume of this serial, a most useful table of contents and special index of names of plants and details treated of in all the papers in the ten volumes has been added by Herr Zopf. This enables the student at once to refer to any given plant, or even to the part of it described in the various papers.

\section{W. R. MCNAB}

THE ROYAL NAVAL COLLEGE, GREENWTCH

N February I, I873, the Royal Naval College was opened at Greenwich, "for the purpose of providing for the education of naval officers of all ranks above that of midshipman in all branches of theoretical and scientific study bearing upon their profession." The first annual report on the Royal Naval College thus established has been recently presented to both Houses of Parliament.

When the College was established it was determined by the Admiralty to bring together in it all the necessary means both for the higher education of naval officers and also of others connected with the navy. During the session which terminated last year four captains, four commanders, ninety-three lieutenants, and eight navigating-lieutenants joined the college as students, but of these only one captain, thirty-three lieutenants, and three navigating-lieutenants went through the whole nine months' course, although one captain, two commanders, fifty lieutenants, and three navigating-lieutenants underwent the final examination. Besides these officers, who may all be regarded as being purely voluntary students, there was also a large number of others studying at the college, with a view to passing certain examinations, which would qualify them either for promotion or ad. vancement or for appointment to some special branch or department of the service.

Finally, ten private students are reported as having passed through a course of instruction, nine of the number being foreign officers, a fact which testifies to the estimation in which the college is held abroad.

With regard to the subjects of study we find that, besides the course of mathematics, which is compulsory for all students, systematic courses of instruction, extending over the entire session, are given in physics, chemistry, steam, navigation, and nautical astronomy, marine sur. veying, permanent and field fortification, military surveying and drawing, military history, foreign languagesnamely, French, German, and Spanish-and in freehand drawing. Special courses of lectures are also given on various subjects, among which the principal seem to be the Structural Arrangements of Men-of-War, International Law, Naval History, and Practical Ship-building.

\section{TYPICAL LAWS OF HEREDITY ${ }^{1}$}

II.

FIRST let me point out a fact which Quetelet and all writers who have followed in his paths have unaccountably overlooked, and which has an intimate bearing on our work to-night. It is that, although characteristics of plants and animals conform to the law, the reason of their doing so is as yet totally unexplained. The essence of the law is that differences should be wholly due to the collective actions of a host of independent petty influences in various combinations, as was represented by the teeth of the harrow, among which the pellets tumbled in various ways. Now the processes of beredity that limit the number of the children of one class such as giants, that diminish their resemblance to their fathers, and kill many of them, are not petty influences, but very important ones. Any selective tendency is ruin to the law of deviation, yet among the processes of heredity there is the large influence of natural selection. The conclusion is of the greatest importance to our problem. It is, that the processes of heredity must work harmoniously with the law of deviation, and be themselves in some sense conformable to it. Each of the processes must show this conformity separately, quite irrespectively of the rest. It is not an admissible hypothesis that any two or more of them, such as reversion and natural selection, should follow laws so exactly inverse to one another that the one should reform what the other had deformed, because characteristics, in which the relative importance of the various processes is very different, are none the less capable of conforming closely to the typical condition.

When the idea first occurred to me, it became evident that the problem might be solved by the aid of a very moderate amount of experiment. The properties of the law of deviation are not numerous and they are very peculiar. All, therefore, that was needed from experiment was suggestion. I did not want proof, because the theoretical exigencies of the problem would afford that What I wanted was to be started in the right direction.

I will now allude to my experiments. I cast about for some time to find a population possessed of some measurable characteristic that conformed fairly well to the law, and that was suitable for investigation. I determined to take seeds and their weights, and after many preparatory inquiries, fixed upon those of sweet-peas. They were particularly well suited to my purposes; they do not cross-fertilise, which is a very exceptional condition; they are hardy, prolific, of a convenient size to handle, and their weight does not alter when the air is damp or dry. The little pea at the end of the pod, so characteristic of ordinary peas, is absent in sweet peas. I weighed seeds individually, by thousands, and treated them as a census officer would treat a large population. Then I selected with great pains several sets for planting. Each set contained seven little packets, and in each packet were ten seeds, precisely of the same weight. Number one of the packets contained giant seeds, all as nearly as might be of $+3^{\circ}$ of deviation. Number seven contained very

$x$ Lecture delivered at the Royal Institution, Friday evening, February 9, by Francis Galtoa, F.R.S. Coutinued from p. 495. 